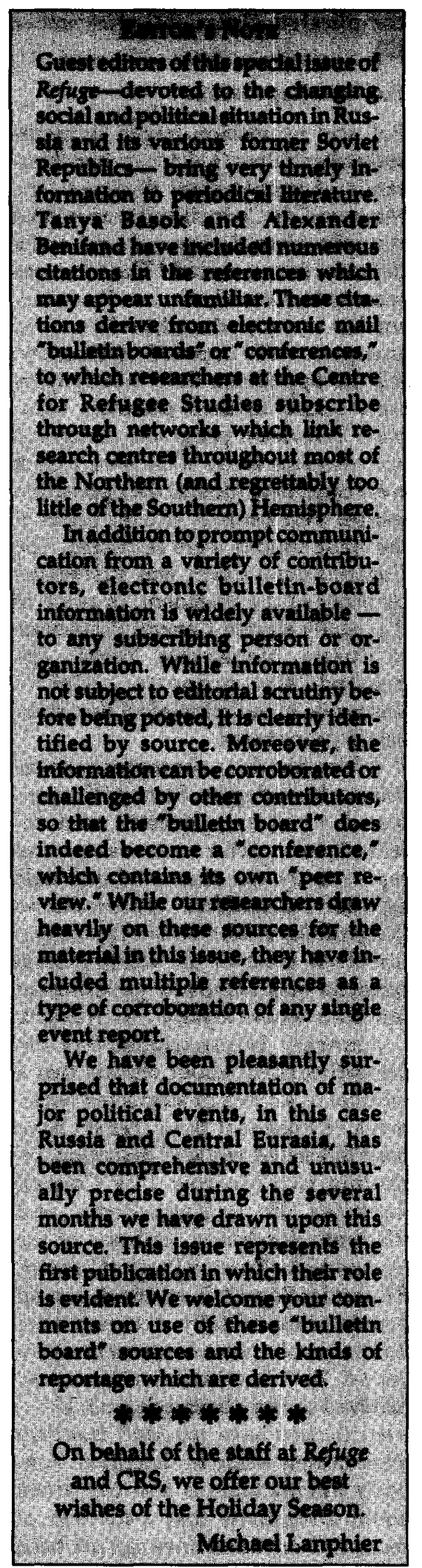

\title{
Recent Political Developments in Russia and Four Types of Potential Refugees
}

\author{
Tanya Basok and Alexander Benifand
}

Once again, an attempt to establish democracy in Russia has been shortlived. Throughout Russia's entire history, democratic forms of government have been sporadic. Most of the time, the country has been ruled either individually or collectively by autocrats; monarchy survived in Russia long after it was abolished in European countries. The rule of the czar was truly dictatorial. Even when the ruling czar allowed for the formation of the State Duma (parliament), its activities were kept under his thumb. When the State Duma attempted to become independent of the czar, it was dissolved and new elections were called for. All three Dumas which existed in Russia before the 1917 Revolution had this fate. In the Soviet era, democracy was also illusory. The Soviets of Peoples' Deputies at all levels took orders primarily from their national party bosses, and next from the regional party bosses. Even the electoral candidates to the Soviets had to be approved by the Party, and only the most loyal Party members were selected.

The 1990 parliamentary election was the first democratic election in Russia. During the September-October 1993 confrontation between Yeltsin and Parliament, the media, both in Russia and in the West, were quick to point out that Parliament was controlled by former Communists. This fact was meant to explain the clash between Parliament and the President. What was rarely mentioned was that both Parliamentary Speaker Ruslan Khasbulatov and Vice-President Alexander Rutskoi stood by Yeltsin during the failed August 1991 coup_-both of them were Yeltsin appointees. The Constitutional Court, headed by Valery Zorkin, was also founded by Yeltsin as an organ to approve political and economic reforms. Most members of the so-called "hard-liner" Parliament were actually staunch supporters of the market and political reforms being pursued by Yeltsin. Among the deputies still in Parliament on October 4, 1993 was 33-year-old Oleg Rumyantsev, whose efforts to write a truly democratic constitution for Russia led The Washington Post in 1990 to call him "the James Madison of Russia." The U.S. National Endowment for Democracy awarded his committee with a grant and honoured him as a feature speaker at its 1991 biannual conference (Cohen 1993).

It was this same Parliament which adopted a constitutional amendment enabling Yeltsin to become Russia's president in 1991, ratified his abolition of the Soviet Union in December of that year, and empowered him, for 12 months, to reform the economy by decree. The media also ignored the composition of Yeltsin's cabinet and his body of advisors. Among Yeltsin's key advisors, there are a number of prominent Communist administrators and intellectuals. Yegor Gaidar, the architect of "shock therapy" in Russia, was the economics editor of the Communist Party publication, Pravda, until 1990. Yeltsin's main political adviser, Gennady Burbulis, was a lecturer of scientific communism in Yeltsin's hometown of Sverdlovsk.

Former Communist nomenklatura members have recently come to power, not only in Moscow, but throughout the region. Unlike other former Communist block countries (such as Poland and Czechoslovakia), in which dissidents came to occupy government offices, in Russia, those who used to be in power in the past have taken off their "Communist" hats and have become "Democrats." In most cases they try hard to deny their Communist past. They have embraced 
the policy of privatization (especially when it gives them an opportunity to transfer state property into their own pockets) and they have defended freedom of religion and the press. However, their motto remains "La loi, c'est moi." According to an article which was to appear in Nezavisimaya Gazeta the day after the resistance by Parliament supporters was crushed (but was censored by the authorities), power in Russia remains in the hands of the nomenklatura which is trying to restrict popular political participation (Mironov 1993).

Parliament supported the transition to a market economy, however it wanted this transition to proceed more slowly than advocated by Yeltsin's advisors. In the last two years, numerous disagreements developed between Yeltsin and the Supreme Soviet. These disagreements were not over the major political and economic course that the country had adopted, but over specific measures. With all its shortcomings, Parliament was a legitimate institution, able to keep Yeltsin and his associates in check. Parliament prevented Yeltsin from arbitrary rule; it challenged his decrees and political resolutions; it prevented him from unilateral decisions on appointments and dismissals; it regulated the distribution of power and privilege; and it oversaw changes in social policies and other important matters. This is not to say that Parliament was a true defender of the people's interests. Good intentions of some deputies notwithstanding, Parliament was also interested in securing its own power and privilege. Whereas in 1991, Yeltsin enjoyed an absolute majority in Parliament, by the spring of 1993 , as little as 20 percent of Parliament supported his measures (Kagarlitsky 1993, October 15).

It was this growing opposition to Yeltsin's absolute rule that he wanted to eliminate once and for all. Yeltsin tried to dissolve Parliament in December 1992 and again in March 1993 however, both attempts failed. In September Yeltsin became bolder; first he evicted Vice-President Rutskoi from the Kremlin; and then he disbanded Parliament on September 21; finally, Yeltsin quelled the resistance of Parliament members and their supporters who had occupied the White House, with a forceful attack using artillery on October 4, 1993.

As Boris Kagarlitsky, a former Moscow City Council deputy and leader of the Labour Party suggests, Parliament was the author of its own demise; it had given Yeltsin emergency powers; it had aided in the creation of the heads of local administrations with a system of presidential appointments; it had undermined the rights of the local Soviets; it had created the post of Executive President of Russia; it had brought into the government Yegor Gaidar and approved his extremist economic policies; and it had concentrated unlimited power in the President's hands (Kagarlitsky 1993, October 15).

When Yeltsin dissolved Parliament and all regional Soviets, it was a declaration that rule by law no longer existed in Russia. By crushing the resistance of Parliament members and their supporters, Yeltsin confirmed that his ruling principle is "might is right." He resorted to "gun diplomacy" with the blessing of the West, and became the absolute ruler of Russia. As John Gray stated, "He [Yeltsin] has assumed the powers of a czar and begun to act like a czar" (Gray 1993, October 20). If the present draft constitution is approved, Yeltsin will have vast powers over security policy and personnel. The President would become the "supreme commander in chief" of the armed forces and would be able to appoint and remove the "high command" of the military, without consulting the Federal Assembly. He will be in a position to form and head the Security Council, and would have the authority to approve Russia's military doctrine (Lepingwell 1993).

A spokesman for the nationalist Russian People's Union has observed that the draft was "a constitution of an almost unrestricted monarchy." Sergei Rogov, of the centrist Civic Union criticized the draft for making the procedure of presidential impeachment too complicated (Tolz 1993, November 12).

\section{Political Repression}

Political repression began immediately after Yeltsin's victory when thousands of people were detained. The Moscow City Council and the regional councils were disbanded and some deputies were arrested. ${ }^{1}$ The detainees were systematically beaten. Press censorship was introduced, and a state of emergency was imposed on Moscow. All the opposition daily newspapers were seized or their premises occupied. Television programs which did not reflect the views of the government were cancelled. Most of the opposition parties were banned, and the rights of the trade unions were restricted. The Constitutional Court was suspended by order of the President. In place of the legally elected General Prosecutor of Russia, Stepankov, Yeltsin appointed his supporter Aleksei Kazannik, in violation of all the established procedures.

After a few days, the repression was softened to a degree. Some of the people who had been arrested were released, and prior censorship was replaced by the threat of reprisals against dissident publications (Kagarlitsky 1993, October 15). Yeltsin dissolved most of the existing local councils and removed government ministers whose loyalty was in doubt.

Amnesty International has expressed concern about reports that a number of known or suspected opponents of President Boris Yeltsin have been ill-treated while in detention, including two Moscow City Council deputies, Boris Kagarlitsky and Vladimir Kondratov, and one of the leaders of the Russian Party of Labour, Alexander Segal. ${ }^{2}$ Over one thousand people were initially detained after fighting broke out in Moscow on October 4-5, 1993, but the majority are now believed to have been released. However, dozens have reported that they were beaten while in detention. Amnesty International is also concerned about allegations that a number of those still detained have not yet been 
charged, and that at least one has been denied access to his lawyer (Naylor 1993). It has been reported that Sergei Baburin, a nationalist member of Parliament, was detained and tortured in the Moscow police headquarters, and subjected to a mock execution (Larsen 1993). Vladimir Klebanov, a Brezhnevera dissident and a member of the Constitutional Committee of the dissolved Parliament, was detained by the police on October 16, 1993, because he did not have a domicile registration stamp in his passport (Glasnet Info 1993).

\section{Censorship of the Press}

Media censorship and other forms of state repression began immediately after the dissolution of Parliament. On October 20, 1993, a group of Russian journalists accused the security forces of arbitrarily beating and arresting correspondents during the state of emergency in Moscow. Reporters stated that during the tragic events of October 3 and 4, 1993 in Moscow, seven reporters were killed and 76 were wounded by the militia (Tolz 1993, October 22, a).

Parliament's paper, Rossiyskaya Gazeta, was shut down soon after Yeltsin's September 21 suspension of Parliament; only to reopen a few days later with a new editor and a pro-government line. Along with a dozen other publications, Pravda, which is loosely associated with the Communist Party of the Russian Federation, and Sovetskaya Rossiya, a proSoviet nationalist paper, were suppressed after the armed clashes of October 3 and 4. Pravda and Sovetskay Rossiya were required by the Press and Information Ministry to be re-registered. It was made clear that re-registration would be granted only if the newspapers changed their names, replaced their editors and softened their editorial lines. This was in direct violation of the recently adopted Press Law, which makes it clear that news publications can be shut down or required to re-register only for reasons strictly defined under a court order (Clarke 1993, October 29). Pravda reappeared on November 2, 1993. Although its journalists refused to change the name of the paper, they did replace the chief editor, Gennadii Seleznev, with Viktor Linnik, a former Washington correspondent for Pravda (Teague and Slater 1993).

Additional measures have also been taken to stifle criticism of the regime. Staff of Nezavisimaya Gazeta, a sharp and persistent critic of the regime since the September 21 dissolution of Parliament, have received numerous threats. The editor of Nezavisimaya Gazeta, Vitaly Tretyakov, said he was told by Press Ministry officials that he may be removed as editor and the newspaper re-registered as a government organ because of its excessively independent stance (Clarke 1993, October 29). On October 29, an Ostankino TV show, "Press-Express," alleged that the authorities secretly ordered the Russian Ministry of Communications not to sell subscriptions to this newspaper (Wishnevsky 1993, November 2). Similarly, Independent Television (NTV), the first private television company in Russia, which started broadcasting October 10, 1993, has been under attack by the Federal Information Centre (ibid.).

\section{Parliamentary Elections}

Having dissolved Parliament, Yeltsin called for elections on December 12, 1993 for the Government Duma, and Presidential elections in June 1994. In the opinion of some analysts, the promise of submitting his own political future to the judgment of Russian voters has legitimized his actions in recent weeks (Bohlen 1993). Later he backed away from an early presidential election and decided to stay in power until 1996, thus undermining the legitimacy of his earlier measure.

An important question is, 'how free are the parliamentary elections going to be?' Yeltsin promised that all parties running for Parliament would be granted equal rights and access to the media, but many opposition parties have complained that the pro-Yeltsin bloc, which includes many key ministers and specifically the Information Minister, has a strong advantage in media coverage (Reuters 1993). Indeed, on October 27, leaders of major political blocs (including Gennady Zyuganov of the Communist Party of the Russian Federation), were each given several minates of television time to express their views. This brief exposure contrasted sharply with the extensive coverage given to the President, his officials and the regime's policies (Clarke 1993, October 29). Even deputy chairman of Ostankino Television, Valentin Lazutkin, recently acknowledged the biases in electoral coverage (Tolz 1993. November 8, a).

Grigorii Yavlinsky, the reformist leader of a democratically oriented election bloc and Presidential candidate, criticized the forthcoming elections as, "a far cry not only from democracy but eyen from simple logic." Yavlinsky also pointed out that the pro-Yeltsin Russia's Choice bloc had virtually unassailable advantages over other parties since its list of candidates included key ministers (Slater 1993, October 29). He told Komsomolskaya Pravda on November 9, 1993, that the "present parliamentary elections are being held by an authoritarian regime in order to strengthen its position and are far from democratic" (Rahr 1993, November 10).

According to B. Kagarlitsky, a former Moscow city deputy, Russian elections are prepared by the authorities, under the control of the authorities, and according to rules devised by the authorities. Fur hermore, the new parliament, convoked by a simple presidential decree in the absence of a law on elections or a law on government, will be subject to dissolution at any time by the same method. In fact, the powers which the new Parliament is to possess have ndt been clarified. In the election campaign, the Presidential administration is intervening directly and openly on the side of the "Russia's Choice" coalition. The Central Electoral Commission, appointed by Yeltsin and composed mainly of "turncoat" former deputes, is denying the right to participate in its work-not only to representatives of the opposition, but also to anyone with a degree

Refuge, Vol. 13, No. 7 (November-December 1993) 
of competence (Kagarlitsky 1993, November 10).

Moscow News has argued that "the number of reports in the state-run electronic and print media on the activities of the pro-Yeltsin "Russia's Choice" bloc is so high that not only the President's opponents, but even his supporters from other blocs cannot dream of such publicity. On October 20, 1993, the newspaper Kommersant criticized the Deputy Chief of the presidential apparatus, Vyacheslav Volkov, for stating, "with full confidence" at an October 19, 1993 press conference, that the party Russia's Choice, would get up to 38 percent of seats in the new parliament. The newspaper said such statements cast doubt on the fairness of the election campaign (Tolz 1993, October 22, b).

In an interview with Delovoi Mir on October 20, 1993, the leader of the reformist Republican Party, Vyacheslav Shostakovsky, expressed his concern about the bloc's electoral list, which includes a number of members of the current government. This situation was also criticized by the leaders of the Russian Movement for Democratic Reforms, Gavril Popov and Anatoli Sobchak. Shostakovsky said that the privileged position enjoyed by Russia's Choice, compared to other blocs, would likely win it an overwhelming majority of seats in the new parliament. He said that he feared there would be no "constructive opposition" in Parliament (Tolz 1993, October 22, c).

Various opposition parties have complained to observers from the European Community of bias and irregularities in the election campaign. Sergei Baburin, the leader of the right-wing Russian All-People's Union, said that his telephone line had been cut off, while Communist Party leader, Gennadii Zyuganov, complained that his protests to the Russian government about media bias had gone unanswered. More serious allegations were made by Nikolai Travkin, of the Democratic Party, who accused local leaders appointed by the President of using their office to collect signatures for themselves. On November 4, 1993 , Ostankino TV reported instances of paying 20,000 rubles for 100 signatures and quoted Arkadii Volsky of the Civic Union as saying that other parties were buying signatures for packets of cigarettes (Slater 1993, November 5).

Yeltsin has ordered a special court to be set up to ensure the independence and accessibility of the media for all candidates in Russia's Parliamentary elections (Reuters 1993). Given that Yeltsin himself appointed the judges to this court, it is unlikely that they will be able to make impartial decisions. Without sufficient time allowed for candidates to run their campaigns, and without the means to do so, voters will still just have to vote for deputies they know nothing about, as they did in pre-Gorbachev times.

Even though international observers have been invited, the Central Electoral Commission has ruled that all international observers must be officially registered and that if the commission considers the actions of observers to be "incompatible with their status," it will be entitled to have them deported (Kagarlitsky 1993, November 10).

\section{Lack of Internal and External Opposition}

Voices of internal opposition to Yeltsin's absolute rule are few and far between. A notable exception was an open letter signed by eight renowned Russian academics, in which they stated that Yeltsin's authorities took advantage of "the amoral union of Rutskoi's supporters with extremist and fascist forces" in order to provoke violence and establish dictatorial rule. Listing a long series of violations of human and political rights by Yeltsin's regime, the statement calls on "all those to whom the free and democratic future of Russia is genuinely dear [to join in] a broad, non-violent opposition bloc" in defense of civil freedoms and the rule of law (Clarke 1993, October 8 ). Some human rights activists of the Brezhnev era have reacted quickly to the abuse of civil rights occurring throughout the country, but one prob- lem is that many of them still remain in the background of Russian political life. The dissidents of the Brezhnev era-those sent to the psychiatric prisons-have not been rehabilitated, and are considered pariahs (Malakhin 1993). Furthermore, it seems that the majority of Russian citizens prefer the "iron fist," to democracy, which, according to them, has brought nothing but high inflation, impoverishment and rising crime.

Most Western governments have applauded Yeltsin's success in crushing the "hard-liners," which were supposedly obstructing the transition to a market economy. They have been willing to close their eyes to the abuse of human rights and the absence of free expression. The U.S. Secretary of State, Warren Christopher, even promised "technical support" for Yeltsin and $\$ 10$ million to stage the election.

There are several reasons why the United States has offered unconditional support to Yeltsin. First, the persistence of the "Cold War" mentality has coloured the perception of Russia's internal politics, which is still viewed in simplistic dichotomous terms as a struggle between market forces, on the one hand, and "Communists," on the other.

Any form of opposition to the market transition, however mild, is categorized as "Communist," and actions taken by the "market supporters" against them are cheered. Second, there is a fear that the possible return to power of the perceived "hard-liners," will put an end to present East-West détente and will lead to an escalation of the arms race. Third, Yeltsin has demonstrated his commitment to sweeping market reforms proposed by the International Monetary Fund, whereas Parliament advocated a more cautious approach. Western countries have always preferred investing in those countries which accept IMF recommendations. Given that the United States and other Western countries are interested in expanding their markets in Russia, it is hardly surprising that they are willing to support those members of the political elite who can guar- 
antee favourable conditions for investment. ${ }^{3}$

\section{Economic Collapse}

Advocates of a market economy argued that what the Russian economy needed was "shocktherapy." The transition to a market economy began with the sudden removal of price controls on January 2, 1992. This provoked a rapid increase in prices, which far outpaced wage increases, and pushed an estimated 85-90 percent of the population below the official poverty line.

In 1992, prices increased 2,500 percent. Soon after the liberalization of price controls, industrial production collapsed due to the lack of credit to pay workers and suppliers. The easing of monetary policy in the summer of 1992 failed to bring a recovery, and by the end of the year, Russia's GDP had fallen by 22 percent, twice the rate of decline in 1991. Consumer spending fell by 38 percent. Kiosks offered imported goods at prices beyond the reach of 90 percent of the population (The Toronto Star 1993; Kotz 1993).

The economy continued to falter in 1993. During the first nine months of the year, GDP and industrial output were 11 percent and 16.5 percent, respectively-lower than in the same period of 1992 (Bush 1993, November 4). For most workers, compensation has been inadequate and erratic. Real per capita incomes have plunged to Third World levels, and recent World Bank figures rank Russian living standards as comparable to those in Mexico (Clarke 1993, October 1). According to the newspaper, Trud, increases in average wages between January 1992 and October 1993 totalled only 44 percent of the increase in consumer prices (Clarke 1993, November 12). At the same time, the budget deficit has continued to escalate.

According to Finance Minister Boris Fedorov, the budget deficit for 1993 could rise to 22.2 trillion rubles, or 14 percent of GDP, considerably higher than the latest target of 17 trillion rubles or 10 percent of GDP (Bush 1993, November 12).
The head of the Federal Employment Service, Fedor Prokopov, stated that there were 706,000 people listed as officially jobless; 968,000 listed as out of work; and 3.7 million on unpaid or part-time leave during the first half of 1993. Prokopov warned that the number of unemployed could rise to 10 to 12 million in 1994. During the first eight months of 1993, a total of 18.1 billion rubles (roughly $\$ 15$ million) was paid out in unemployment benefits (Bush 1993, October 22).

Residents of Russia's urban centres are experiencing what might be called "financial embarrassment." In a recent survey, only one respondent in a hundred said that his or her family was "quite well provided for." A total of 2.6 percent said their living standards were above average, and 26 percent believed their families to be of "moderate means." The rest thought they were poor (23.6 percent), and some considered themselves "not poor but below average" (Kryshtanovskaya and Skorobogatko 1993). According to Kommersant, a leading Russian business newspaper, only about 2 percent of Russians, or three million people, have the income to live at a middleclass, Western European, level (Covert Action Quarterly 1993). A hike in valueadded taxes and excise taxes on energy sources, predicted to be set in place after the December 12, 1993 elections (Clark 1993, November 12), will create even more hardships among the Russian population.

The decline in Russia's economy has incurred a heavy social cost. In 1992, some 250,000 people died in Russia as a result of accidents, poisoning, injuries, and so-called "unnatural causes" of death, including murder, suicide and alcohol poisoning. Overall mortality rose by almost 7 percent over the year, while the number of "unnatural" deaths increased by 20 percent.

Mortality among teenagers under the age of 18 is growing at the fastest rate and is directly attributable to growing alcoholism and drug abuse. Infants also suffer from poor health; in 1985 , one out of every 11 newborns was sick, while today one child out of every five, is unhealthy (Ivchenko 1993).

\section{Rising Crime}

One of the consequences of the transition to a market economy has been the emergence of organized crime as a central feature of Russian life. As Stephen Cohen puts it, economic reforms have given rise to a "Klondike 'capitalist' profiteering in state goods and natural resources - 'corruptalism.'" (Cohen 1993). An estimated one-third of raw material exports are illegal. In the fall of 1992, a military transport plane loaded with titanium was seized at Koltsovo Airport. The scale of illegal exporting is demonstrated in Latvia which exported 238,000 tons of nonferrous metals in 1992, although it did not produce any. The chairman of Russia's central bank has admitted that at least $\$ 20$ billion of the $\$ 24$ billion of Western aid has been illegally taken out of the country and deposited in Western banks (Kotz 1993).

According to some reports, the most corrupt government institutions are the law enforcement agencies, the state property administration, the tax office, the customs services, and foreign trade organizations. According to Alexander Mikhailov, head of the Public Relations Office at the Moscow Administration of the Ministry of Security, almost all the directors of state enterprises in the Moscow area had set up joint ventures and small businesses linked to their state enterprises. There are also cases of government bodies directly involved in business activities (Yasmann 1993).

Yeltsin made a statement recently that Russia is becoming "a Mafia great power" (Kotz 1993). This opinion is generally shared by the public. In a survey of over 1,500 residents of 12 cities in four Russian regions, over half of the respondents could not describe the present socio-political system in Russia, and 9.2 percent of the respondents said that the system is characterized by "chaos, anarchy and rampant lawlessness." When asked about who rules Russia today, almost one-quarter of the respondents ( 23.3 percent) said 
"Mafia," while only 16.3 percent thought it was Yeltsin who ruled Russia (Kryshtanovskaya and Skorobogatko 1993).

According to the Department of Criminal Statistics, crime has increased dramatically since the end of the Soviet Era. In 1992, 3.8 million crimes were committed in the CIS, an increase of 24 percent from 1991. The number of robberies and assaults rose by 50 percent, thefts rose by 58 percent, violent crimes rose by 25 percent, and murders rose by 40 percent. In the same year, 1.6 million people were convicted of crimes in the CIS (Argumenti i Fakti 1993).

\section{Yearning for "Iron Fist"}

The growing chaos in the country has made the former system of totalitarian control look attractive. Moscow City Hall Press Centre disseminated a report that there have been numerous appeals to President Yeltsin and Mayor Luzhkov from labour collectives, asking for the state of emergency to be extended. According to the All-Russia Centre for the Study of Public Opinion on Social and Economic Questions, 75 percent of respondents surveyed favoured the extension of the state of emergency in Moscow, while only 16 percent opposed it. What is also remarkable about this survey is that there were no significant differences by age. Moreover, the proportion of people who agreed to the extension of the state of emergency was higher among those with higher education than among the less educated (74 and 69 percent respectively) (Izvestia Daily 1993, 1,4).

However, nostalgia for a firm government does not necessarily reflect a preference for Yeltsin and his policies. According to Yuri Levada, the best known Russian pollster, a bare fifth of Russians believe they are better off since the start of market reform. Most want gradual rather than radical economic reform; and they favour candidates who will defend the poor over those who advocate individualism (Gray 1993). According to another poll, sponsored by U.S. News and World Re- port Magazine, and conducted by Moscow's Institute for Comparative Social Research, less than one-third of Russian people said Yeltsin deserved to be president again, although about half of the 1,000 people sampled replied that they approved of the way he was handling his job (Reuters 1993).

It seems that to many Russians it does not matter who is in power, as long as the government is autocratic. Nor is there strong opposition to having the Communists in power. According to yet another opinion poll conducted by the Russian TV program "Obschchestvennoe mnenie" (public opinion) on October 28, 1993, 38 percent of those surveyed supported the leader of the Communist Party, Gennadii Zyuganov (Rahr 1993, October 29).

\section{Scapegoating Ethnic Minorities}

The elimination of political competition did not help Yeltsin solve the economic crisis in Russia. Once the so-called "hard-liners" were out of the picture, other social groups had to be blamed for the continued economic woes of the Russian population. Such scapegoats were easily found.

Most Russians blame Caucasians (those from the Caucasus) for the dramatic rise in crime in Moscow. Government officials, police and even the TV news claim that Caucasians commit 80 percent of the crimes in Moscow. In order to fight rising crime, the Moscow Police used the state of emergency as an opportunity to clear the city of thousands of Armenians, Georgians, Azerbaijanis and other unpopular ethnic groups from the southern Russian republics, who had no domicile registration permits (propiska). Moscow Traffic Police ordered its officers to stop all cars, driven by Caucasians and demand identity papers. Police also confiscated cars and detained and deported their owners. Many of the deported people were already refugees from Azerbaijan, Abkhazia, Georgia, Chechnya and regions of conflict in the former Soviet Union (Gray 1993; Kaplan 1993). The harassment of people from these re- gions ranged from document checks, beatings and extortion, to sweeps of the local markets and deportations from the capital. Mayor Yury Luzhkov seriously aggravated the situation with a call on Muscovites to help police enforce the state of emergency. ITARTASS reports that 40,000 residents of Moscow signed up as "volunteer guards [to] patrol the city" (Moscow Times 1993). At one Moscow food market, Russian merchants reportedly helped police turn over fruit stands, beat and arrest traders from Azerbaijan (Akai 1993).

The operation to clear the city of illegal residents was targeted almost exclusively at people with dark complexions. Over 5,000 people were deported within the first two weeks alone, while thousands of illegal residents who were ethnic Russians or otherwise white-skinned, continued to enjoy their stay in Moscow.

This harassment of people of colour has been going on for some time in Moscow, and indeed such racism has always existed in the Soviet Union. People of colour are stopped and harassed daily, regularly paying bribes to the police to avoid arrest. Now the government, using the pretext of the propiska system, has institutionalized this racism (Akai 1993).

Once again, the state is blaming ethnic minorities for the economic collapse and rising crime in the country. The people are led to believe that Caucasians, some of whom are involved in petty commerce, are responsible for soaring prices. At the present time, they serve as convenient scapegoats. As D. Ostalskiy, Segodnya's editor in chief, commented, "it is much easier to deport all persons of Caucasian nationality from Moscow along with southern vegetables from Moscow markets than to engage in the painstaking work of eliminating criminal gangs" (Ostalskiy 1993, 1).

Once Moscow is "cleansed" of these people, other visible minorities will become victimized by the racist mobs inspired by the Police. Already the OMON (special purpose militia detachment) has detained 95 Kurds who 
were meeting in Moscow's Pushkin Square on October 14, 1993. Sources at the Moscow main Interior Department told ITAR-TASS that the detainment was part of the state of emergency arrangements to expel foreigners without residence permits from the capital (ITAR-TASS 1993).

\section{Separatist Challenges}

The secessionist movements of the resource-rich regions has been one of the biggest challenges to Yeltsin's rule. Tatarstan, a large Muslim republic on the Volga with some of the largest oil reserves in Russia, has declared economic independence. Bashkortostan, also Muslim and closely aligned to Tatarstan, with 60 percent of Russia's oil refining capacity, is also moving toward greater independence. A recent joint session of the Bashkir Supreme Soviet Presidium and Council of Ministers reaffirmed that Bashkortostan will work toward further sovereignty. Parliament has also criticized the decision by Yeltsin's administration to try to deprive the republics of their sovereignty and to preserve the Russian Federation as a union (Sheehy 1993, November 9, a). Most leaders of other republics have protested the fact that Russia's Draft Constitution fails to define republics as "sovereign states" (Tolz 1993, November 12).

In the north Caucasus, there is one oil-rich Muslim republic, Chechnya, which has already seceded from Russia. Chechnya refused to hold elections to the Russian Federal Assembly on its territory (Sheehy 1993, November 9, b).

Karelia, a Finnish-speaking republic bordering Finland with an abundance of mineral and forest resources, has declared economic independence. Sakha-Yakutia, in eastern Siberia, is about one-third the size of Canada. It has only one million people, but contains almost all of the former Soviet Union's diamonds (12 percent of global production), the second biggest gold reserves in Russia, as well as newly discovered oil, gas and coal basins. Kalmykia is a small, oil-rich Bud-

dhist republic on the Caspian Sea (Rossiyskaya Gazeta 1993; Covert Action Quarterly 1993).

Most regional councils disapproved of Yeltsin's decision to suspend Parliament. When the latter was defeated on October 4, Yeltsin moved directly to dissolve regional councils as well, thus eliminating political dissent and maintaining strong control over resourcerich areas. He has also adopted this strategy toward the regional councils which have demanded more autonomy. In October, 1993, for instance, Sverdlovsk Oblast declared itself a republic within the Russian Federation, but on November 9, Yeltsin dissolved it-dismissing Governor Eduard Rossell from his post and halting all activities of the regional soviet (Teague 1993; Tolz 1993, November 8, a).

\section{Security Forces}

It is possible that the return to ruling with an "iron fist" will revive the security bodies, regardless of who is in power. Even before the October crisis, the former KGB was regaining some of its past power.

The KGB has broken into domestic and foreign operations since the end of the Cold War. Most of the domestic functions are now with the new Ministry of Security. It is worth pointing out that, contrary to popular expectation, after the reorganization of the $\mathrm{KGB}$, the Ministry of State Security increased its personnel by tens of thousands of people (Vizhutovich 1993). Fred Weir, a Moscow correspondent for seven years, said:

\begin{abstract}
"As far as I know, it's still all there and doing everything it used to; perhaps more." For example, contrary to everything you hear, any Russian who wants to obtain a passport for travel abroad now needs to obtain a razresheniye, or clearance, from the Ministry of Security. All that was abolished years ago by Gorbachev, but it seems that a lot of those old functions are being reestablished. (Covert Action Quarterly 1993).
\end{abstract}

The KGB has infiltrated about 3,000 members into Soviets at various levels (Literaturnaya Gazeta 1993).
In an attempt to deal with state-level corruption, in September 1992, Yeltsin issued a decree which authorized the posting of several thousand state and internal security officers from the former KGB Active Reserve to various government institutions. According to this decree, these officers were to act as advisors and consultants under dual subordination to the central government and the Ministry of Security (Yasmann 1993). However, it appears that these officers have been investigating more than just corruption. In June 1993, Brezhnev-era dissident writer, Anatoly Pristavkin, observed that people were being urged to report to the Regimented Secret Organ (RSO-a branch of the State Security) information concerning their colleague's relatives living abroad, and their ties with foreigners coming to Russia (Pristavkin 1993).

To strengthen its power, in March 1993, The Russian Federation Ministry of Security submitted to the Supreme Soviet for consideration a "Draft Law on Making Changes in and Additions to the Russian Federation Law 'On Operational Investigative Activity in the Russian Federation'," the Russian SFSR Criminal Code and the RSFSR Criminal Procedure Code," and a "Draft Law On Federal State Security Agencies." Political analysts view this as an attempt by the Security to reestablish its former absolute power (Bespalov 1993). Contrary to the provisions of the Russian Constitution, the law would entitle the Ministry of Security to search apartments, bug telephones and scan private correspondence without a warrant from either court or public prosecutors. If adopted, it would also make it obligatory for employees of the Ministry of Internal Affairs to take part in MS operations against foreign spies, and would commit all citizens to serve as the Ministry's secret agents should the latter deem this necessary. Moreover, the report revealed that the Draft Law includes a provision exempting MS agents from prosecution for crimes they commit in order to preserve their anonymity (Wishnevsky 1993, May 
11). The re-installation of the authoritarian rule may make these proposed changes possible and Russia may once again return to the era of dissidents and political prisoners.

\section{Potential Refugees}

In addition to the present flight of refugees from Russia due to the rise of nationalism and the persecution of ethnic minorities, three other types of refugees may be expected to emerge from Russia. First, it is very likely that political repression will prompt some dissenters to leave the country. Second, under fear of deportation from Moscow, many refugees from the southern countries of the former Soviet Union and from the southern regions of Russia, will attempt to move westward, rather than return south. Finally, the independence struggle in some republics of the Russian Federation is likely to provoke a repressive response by Yeltsin, creating yet another group of asylum seekers.

\section{Notes}

1. The detained deputies include Yuri $P$. Sedykh-Bondarenko, the City Council's Deputy Chairman; Viktor A. Kuzin, Deputy Chairman of the Standing Committee on Law, Justice, and the Defense of Civil Rights, co-founder of "Memorial," and cofounder of the first opposition party in the Soviet Union, Democratic Union, in 1988; Viktor Bulgakov, a human rights activist and a prominent member of the "Memorial" Society; and Aleksandr Tsopov (Covici 1993, October 7).

2. Segal, Kagarlitsky and Kondratov were seized by police on October 3,1993, after the failed assault on the Ostankino television centre. They had tried to prevent a pointless and potentially bloody attack on the TV centre by the Rutskoi and Khasbulatov supporters. Over the next 24 hours they were systematically beaten by police. The detainees were told they stood accused of complicity in kdlling two policemen in order to steal their vehicle (Clarke 1993, October 26).

3. The reaction of some members of the American public has contrasted with the official response to Yeltsin's repressions. An American organization, "The Committee for Democratic and Human Rights in Russia," was organized to demand respect for human rights and freedom of the press, assembly and political organization for all in Russia, and to stop repression of trade unionists and democratic activists. See "Russian Human Rights Appeal," distributed by web.apc.org on November 8, 1993.

\section{References}

Akai, Laure. 1993. "Ethnic Cleansing a la Russe." Distributed by krazchenko Qglas.apc.org. Moscow Institute for Study of Recism and Nationalism.

Argumenti i Fakti. 1993. June 13.

Bespalov, Yury. 1993. "State Security Tries to Reclaim its Former Absolute Power." In Izvestia, March 16.

Bohlen, Celestine. 1993. "Yeltsin Backs Away from Early Presidential Election." In The New York Times, November 7.

Bush, Keith. 1993. "Higher Budget Deficit Foreseen." In Radio Free Europe, November 12.

- 1993. "Chernomyrdin Reviews the Economic Situation." In Radio Free Europe 212, November 4.

_. 1993. "Latest Unemployment Data." In Radio Free Europe 204, October 22.

Clarke, Renfrey. 1993. "Russia Plunges Toward the Third World." Distributed by web.apc.org, November 12.

- 1993. "Pressures Remain Intense on Russian Media." Distributed by web:glasnost.news, October 29.

- 1993. "Repression Will Never be as Easy Again." Distributed by web:labr.cis, October 26, 1993.

. 1993. "New Democratic Opposition in Russia-Russian Democrats Call for Opposition Bloc." Distributed by glas:krazchenko in web:glasnost.news, Oct. 8.

_. 1993. "To Build Capitalism, Yeltsin Dumps Democracy." Distributed by schneider@oln.comlink.apc.org in web:reg.ussr, October 1.

Cohen, Stephen. 1993. "Striking Down Parliament was the Act of a Dictator." In The Washington Post National Weekly Edition, October 18-24.

Covert Action Quarterly. 1993. "An Interview with Fred Weir from Moscow." Summer Issue.

Covici, John. 1993. "Moscow City Coundil - Moscow Elects New Mayor and Council?" Schiller Institute, Washington, DC., October 7.

Glasnet Info. 1993. "Eternal dissident." No. 9, October 20.

Gray, John. 1993. "Life Under the New Czar." In The Globe and Mail, October 20.

- 1993. "Yeltsin Closes Papers, TV Show. Moscow Police Crack Down on Suspected Criminals." In The Globe and Mail, October 15.

ITAR-TASS. 1993. "Omon Detains 95 Kurds." October 15.

Ivchenko, Lidia. 1993. "A Quarter of a Million Russian Citizens Die of Unnatural Causes." In Izvestia, March 3.

Izvestia Daily. 1993. "Support for Extending State of Emergency." October 16.

Kagarlitsky, Boris. 1993. "Pre-election Machinations." From World Radio Transcription Services, November 10.
Kagarlitaky, Boris. 1993. "On the Ruins of the Constitution." Distributed by krazschenko Oglas.apc.org in igc:apc.labor, October 15.

Kaplan, Fred. 1993. "Moscow Cracks Down on Outsiders,Police Take Advantage of State of Emergency to Drive Many Ethnics from City." In The Boston Globe, October 14.

Kotz, David M. 1993. "Shock Therapy in Russia. The Cure that Could Kill." In The Nation, April 19.

Kryshtanovskaya, $O$. and Skorobogatko, $T$. 1993. "Provinces Indifferent to Parties, Critical of Social Gaps: Results of Polls." In Moscow News 12, March 19.

Larsen, Poul Funder. 1993. "We Are Facing a Nearly Impossible Choice." Distributed by glas:krazchenko in web:labr.cis, October 22.

Lepingwell, John. 1993. "The Constitution and the Military." In Radio Free Europe, November 12.

Literaturnaya Gazeta. 1993. “KGB - ne lisus Khristos (KGB is not Jesus Christ)." June.

Malakhin, V. 1993. "Russia dissidents: low profile." In Izvestia Daily, October 15.

Mironov, Vladimir. 1993. Grazhdanskaya voina ili grazhdanskoe obschestvo? V hohote naroda rozhdaetsia novoe gosudarstvo ("Civil War or Civic Society? New State is Emerging While People are Laughing)." Translated by Voronov, Anatoly (Abridged), Nezavisimaya Gazeta Daily, October 6, 1993.

Moscow Times. 1993. "Police Raids: Crackdown of Pogrom?" October 12.

Naylor, Hilary. 1993. "Russia: Amnesty International Concerned at Reports of Ill-Treatment of Political Opponents in Moscow." Distributed by hnaylor @igc.apc.org, October 17.

Ostalskiy, D. 1993. "State of Emergency: Rake Instead of Scalpel." Segodnya 66, October 16.

Pristavkin, Anatoly. 1993. "Privet of Gracheva ili KGB $v$ moei zhizni (Regards from Grachev or KGB in my life)." In Literaturnaya Gazeta 23, June 9.

Rahr, Alexander. 1993. "Yvlinsky Criticizes Yeltsin." In Radio Free Europe, November 10.

_. 1993. "Communist Leader Does Well in Poll." In Radio Free Europe 209, October 29.

Reuters. 1993. "Russians Don't Want Yeltsin Reelected." In The Globe and Mail, October 30.

Rossiyskaya Gazeta. 1993. "Bashkortostan Discusses 'Sovereignization'." October 12.

Sheehy, Ann. 1993. "Bashkortostan parliament remains defiant." In Radio Free Europe, November 9, $a$.

. 1993. "Chechnya and the Elections." In Radio Free Europe, November 9, b.

Slater, Wendy. 1993. "Allegations of Corruption in Election Campaign." In Radio Free Europe 213, November 5.

_ـ 1993. "Elections 'a Far Cry From Democracy;' Says Yavlinsky." In Radio Free Europe 209, October 29. 